\title{
Developing Culture-Based English Instructional Materials for Grade VII of Junior High School Students
}

\author{
${ }^{1}$ Wiwiek Afifah, ${ }^{2}$ Darmiyati Zuchdi \\ Graduate School of Yogyakarta State University \\ ${ }^{1}$ wiwiekafifah.2018@student.uny.ac.id
}

\begin{abstract}
The research aims at developing culture-based English instructional materials (henceforth, CBEIM) for grade VII of Junior High School students and reveal its final product representation in terms of its effectiveness. The research design was a research and development. The procedure of product development consisted of conducting needs analysis, designing course grids, developing the first draft, implementing the final draft, and evaluating the final product. The product implementation consisted of the $1^{\text {st }}$ tryout involving 4 students from Yogyakarta State Junior High School (henceforth, Y-SJHS) 10, the $2^{\text {nd }}$ tryout involving 34 students from Y-SJHS 7, and there were 68 students involved in the $3^{\text {rd }}$ tryout. They were from Y-SJHS 9 and Y-SJHS 10. The data were collected by using evaluation sheets, an English achievement test, questionnaire to measure students' level of internalization and actualization toward culture values, and questionnaires for teachers' responses. The data were analyzed by t-test using paired and independent sample with the gain score. The research finding reveals: 1) based on the content expert validation, CBEIM was very good by the aspect of content, language, learning, culture, presentation, and graphical design, whereas based on the graphical design expert, CBEIM was good. 2) Having been implemented, the final product representation was proven to be effective. The students in the experiment classes got a higher improvement than those in the control classes. The statistical calculation of independent samples test with gain score of the English test from the two groups shows the $t$ values of 2.931 with the $p=0.004<0.05$, while the t-test for equality of means of culture values, $t$ value reached 2.524 and its significance of 2 -tailed reached $p=0.037<0.05$, alpha value $(\alpha=0.05)$. Since the gain score is smaller than 0.05, CBEIM demonstrates that it can show a significant difference between the experiment and control classess in encouraging students to internalize and actualize the culture values.
\end{abstract}

Keywords: culture, internalization, actualization, instructional materials

How to Cite: Afifah, W. and Zuchdi, D. (2018). Developing culture-based English instructional materials for grade VII of Junior High School Students. English Language Teaching Educational Journal, 1(2), 76-96. 


\section{INTRODUCTION}

The problem of school gang fights, bullying, and drug-abuse frequently appeared in the mass media. Those matters of fact are the evidence of low level of Indonesian morality. Add to this, there are several factors supporting the complicated conditions such as scarcity of values implementation. In fact, the flawed culture which is going to be sinking can be well made by bringing an education amongst them. It is because the education means the process of a culture establishment (Zuchdi, 2009). Responding to the worrying problems, being a part of education components, it is a must for us to think about developing appropriate instructional materials equipped with positive culture values dedicated to the students. This idea is supported by some scholars who admitted that instructional materials bring an important role in teaching and learning process. Tan-Florendo (2012) states that teachers can use instructional materials when planning and carrying out instruction in such a way that they are undoubtedly important as teaching resource materials. Regard to this, Murphey (1992) as cited by Lorenzutti, (2014) says that since there are some elements in culture such as social values, human relationship, spiritually, patriotism and dissent and these can be used to train and to grow students' feeling of empathy, honesty, politeness, wisdom, discipline, caring, loyalty, indeed, it can be practiced as a mediation to build a character. In line with Murphey's idea, Peacock (1998) as cited by Saifer, et al. (2011) reported that when the school acknowledged and taught cultural heritages, it had a significant success in educating the students. Kanoksilapatham (2014) also reported that developing young learners in grade 4 by using local culture awareness and global English as an integrated instruction could reach a higher gain score. In line with the finding of positive responses toward the culture-based tasks, Doganay, Ashirimbetova, \& Davis (2013) also proved that students increased their English communicative competences and cultural sensibility. Based on the previous studies, culture had proven to be one of the leading ways to teach English as a foreign language.

Dealing with teaching materials, Tomlinson (2008) and Dudley-Evans \& Jo (1998) highlight that materials should be framed into an interesting, motivating, stimulating on never ending communication and question-answer, even including activities which can encourage learners to optimize the environment outside their classrooms. Tomlinson (2012) also states that materials refer to "anything that can be used to facilitate learning of a language. Add to the idea, Nation \& Macalister (2010) suggest applying three principles in developing language textbook: 1) it serves substantial quantities of interesting comprehensible inputs. 2) Language textbook should provide activities aimed to increase fluency, and 3) language textbook, especially for English as foreign language textbook should spend focusing on using the target language. Furthermore, Atkinson (2012) highlights that "if culture is considerably more dynamic and negotiated than previously believed, then language is close behind". Ho (2009) also points out that "language and culture have inextricable and dependent relationship". Moreover Kramsch (1998) in Ho (2009) emphasizes that since language shows kind of expressions and able to 
symbolize cultural reality, it makes language and culture are bounded together. Grave (2001) also stated that language is used in a context and learners use it by considering the purpose, style, register, and topic. There are many studies dealing with culture and language teaching. It is in line with the statement conveyed by her that "the role of culture in language learning is receiving increasing attention", thus Damen (1986) as cited by Grave (2001) names culture as the fifth dimension of language teaching. Whereas Kramsch (1993) explains that culture will be created and represented through the dialogue between students and students and between students and teachers. Syatrian, et al. (2013) also gave a recommendation that students would easily comprehend the materials when the instructional materials or course books were developed based on the local contents and students' needs. However, they suggested that those materials should be enriched with international contents. Thereby, students could improve their language skills and teachers were assisted in choosing kind of teaching materials to support their teaching and learning process.

However, the government textbook entitled Bahasa Inggris When English Rings a Bell (2013) as the compulsory student's textbook used in Junior High School did not fully match to the students' needs. Based on the interview on 15 of July 2014 with some Yogyakarta English teachers, the students have varying needs. Their current needs are vocabulary enrichment, reading text, grammar, speaking and listening materials, wide range of games, and even moral values to support their mental development process while learning English. The students particularly who were in the early years of JHS were still in a low level of independence, having variety of English language skill provision, low grammar mastery, and low literacy. It was indeed that the government textbook has contained some picture illustrations and gave positive effects for the young learners. The pictures appeared in most of the pages of the textbook could stimulate them to produce the target language. Yet, the language inputs were served in isolated contexts. Take for example, the songs that were served in the pages of $2,23,41,66,83,104,135$ were not meaningful and effective to support students' understanding and actualizing toward the culture values. Otherwise, they were modified with cultural values activities such as comparing the two cultures: Indonesian and English cultures. It must be much more meaningful for students learning English as a foreign language learning. Furthermore, some researches done by Mursyida (2015), Hariyantina, Arifuddin, \& Djuhaeni (2016) also revealed that the textbook was lack of productive skill materials such as no listening materials. Even the textbook contained materials that were irrelevant to the curriculum of 2013 syllabus.

To point out, developing culture-based English instructional materials for Grade VII of JHS needs to be developed. It is expected to support the process of English teaching and learning as well as encouraging and motivating students to internalize and actualize positive culture values. Having learnt English with culture-based instructional materials, students are expected to improve their English skills as well as their level of morality. 
Based on the former ideas, the problems are formulated into: 1) how are the culture-based English instructional materials for Grade VII of Junior High School Students developed and 2) how is the final product of the culture-based English instructional materials for grade VII of Junior High School students represented in terms of its effectiveness.

\section{RESEARCH METHOD}

The research design applied was Research and Development (R\&D) which aimed to develop a product of culture-based English instructional materials modifying of a model developed by Dick, Carey, \& Carey (2005). The model is adapted into five steps: analyze, design, develop, implement, and evaluate. Operationally the implementation was conducted as tryout design and expected to find out the effectiveness of the product. The tryout was designed by conducting pretest-posttest class group control. The tryout design appeared in Table 1.

Table 1. Tryout Design

\begin{tabular}{cccc}
\hline Class & Pretest & Treatment & Posttest \\
A & $\mathrm{T}_{1}$ & $\mathrm{X}_{\mathrm{a}}$ & $\mathrm{T}_{2}$ \\
$\mathrm{~B}$ & $\mathrm{~T}_{1}$ & $\mathrm{X}_{\mathrm{b}}$ & $\mathrm{T}_{2}$ \\
\hline
\end{tabular}

Subjects of the need's analysis and product implementation were students from Y-SJHS of 7, 9, and 10. The underlying consideration was those schools almost had the same characteristics. Their visions were almost similar. They supported their students to be well behaved, having environment awareness, smart, well cultured, having achievement based on a good faith, love the state, and having a higher feeling of nationality. Thus, based on these reasons, the three schools deserved to have the same goals in educating their students and they were agreeable to the purpose of the research. The English teachers who taught in the seventh grade had also been certified by the government as well as upgraded to their professionality. The chosen experiment and control classes for the last product evaluation were from Y-SJHS of 9 and 10. The two groups of classes were chosen based on the English teachers' information. Furthermore, the students of the classes had the same characteristic such as some were active, but some were not. As an addition, students in those classes also had low-level appreciation to the culture values such as, coming late joining the class, having a low attention to the learning process. Therefore, it can be concluded that the class dynamics, the low-level of internalization and actualization toward culture values in the two classes were almost the same. They could be used as the consideration in the experiment phase in order to judge the textbook' quality in term of its effectiveness.

Data collection techniques and instruments used in the research were instrument to evaluate the product, needs analysis instrument, English test items, and culture values questionnaire. The data were analyzed using a Likert scale type and t-test with gain score. The entirely instruments were deserved to be valid since they had been validated based on content and construct validity. 


\section{Research Result and Development}

In developing CBEIM, the procedure was started by analyzing the students' needs, designing, developing, implementing, and evaluating. The analyzing meant the effort to know the factual condition of the schools. The way to conduct the $1^{\text {st }}$ step was by observing the teaching and learning process in some classes, discussing with some teachers, and distributing the questionnaires of the need analysis in the last session of the meeting. Having got the data of the need's analysis, the product was started to be designed.

The summary of need analyses result is presented in Table 2 and the culture that was chosen to be integrated in the textbook was culture proposed by Lorenzutti (2015). He proposed that culture values referred to how people learnt to have social awareness, human relationship, spiritual, patriotism, and to grow the feeling of empathy, honesty, politeness, wisdom, discipline, caring, and loyalty. Yet, realizing a wide range of cultures proposed by Lorenzutti, then the culture values integrated in the culture-based English textbook were taken from the highest percentage chosen by the students.

Table 2. The Result of Need Analysis

\section{No Most Preferred Topics Integrated in Culture}

\section{Number Percent of ages}

Student

$\mathbf{S}$

1 Politeness, responsibility, discipline in a family and society.

$67 \quad 70.53 \%$

Knowing some historical things from Indonesia

$67 \quad 70.53 \%$ and English such as temples, traditional farming tools, traditional weapons, traditional dances, games for children, and any other local creativities serving a local wisdom.

3 Visiting a friend who is sick, helping each other, working together.

$41 \quad 43.16 \%$

4 Indonesian traditional foods, religious ceremony, tools in daily activities, traditional house, and some other things related to human creativities.

5 Knowing some unique or characteristic names from Indonesia and from Western people.

7. Being discipline in family, school, classroom, and $52 \quad 54.74 \%$ in the larger environment.

8. Knowing the local, national, and international

$67 \quad 70.53 \%$ heroes.

9. Realizing the important of being honest in any situations. 
Designing as the $2^{\text {nd }}$ step of the procedure was the effort to prepare the blueprint as the product guideline. It was a course grid design consisting of some aspects. The function of the course grid design automatically was used for guiding the researcher in developing the product in order to be appropriate and match to the students' needs.

The $3^{\text {rd }}$ step was developing the blueprint. The consideration in developing it was to interconnect between the learning approach adapted in the research, culture values, and the result of students' needs within the contents of instructional material. After finishing the rough draft of developing instructional materials, then the product was validated by the content experts. The criteria to recruit the content experts in the research were those whose background knowledge in curriculum and material development, teaching English as a foreign language, and graphical design. They were Prof. Sugirin, Ph. D., Joko Priyana, Ph.D., and Setyo Adi Purwanto, M.Pd. Before the product was implemented to the classroom, the teachers also attempted to show their responses to the product. Having finished those steps, then the product implementation was held in the three schools.

The purpose of product implementation was to find out the empirical data on how the product was used by the students in the class involving many students. The implementation of the research product took six times including pretest and posttest. The implementation was done in $19^{\text {th }}$ of February until $2^{\text {nd }}$ April 2015. The numbers of the students in the experiment class were 68 and 67 in the control class. The experiment class consisted of 30 boys and 38 girls while in the control classes there were 33 boys and 34 girls. The following table shows the quantity of the students in those classes.

Table 3. School \& Students Involved in Tryout

\begin{tabular}{ccc}
\hline School & Experiment & Control \\
\hline SMP N 9 & VII-F (34) & VII-C (34 students) \\
SMP N 10 & VII-B (34) & VII-A (33 students) \\
\hline
\end{tabular}

\section{Product Description}

The product of the research was named as the culture-based English textbook. It was a supplementary printed textbook that covered 121 pages and had colorful pictures. The textbook was divided into four units and all the units reflected the aspects of local or Indonesian culture as well as the target or English cultures. The culture-based English textbook as the supplementary of printed textbook consisted of: (1) preface, (2) table of content, (3) pronunciation guide, (4) unit 1 talking about family, (5) unit 2 talking about historical building and things, (6) unit 3 talking about great people, (7) unit 4 talking about foods and focusing on how to learn the procedure text, 8) bibliography, and 9) listening scripts. Every unit had the same parts; a) let's get ready consisting of some tasks, b) let's act consisting of some learning inputs and some main tasks, c) let's have fun facilitating students to play the game, d) let's do review, a space for doing some exercises, and e) let's have a reflection, 
as the top of the unit in which students were given time to make any reflections after learning English in the class using the culture-based English textbook.

The function of the pronunciation guide in CBEIM became the evidence that this research product also concerned on the productive skill. All the units were arranged systematically and started by the learning objectives. The development of tasks in the units was based on the learning and scientific approach. Family was chosen to be a topic in unit 1 because the researcher intended to integrate Indonesian culture values in the reading text through the characters. Since, values were the very basic things in culture, it was necessary to present the model of people who had a good personality. Historical building and things were the topic set in unit 2. Students were expected to learn many positive values from the cultural heritages possessed by the two nations. For unit 3, the researcher presented some great people. Students were expected to take and learn moral values from them. Specifically, from the reading text and learning activities, students were trained how to be leader, to be confident, optimist, and loyal. Reading and other activities provided in every units is presented in Figure 1 and 2.

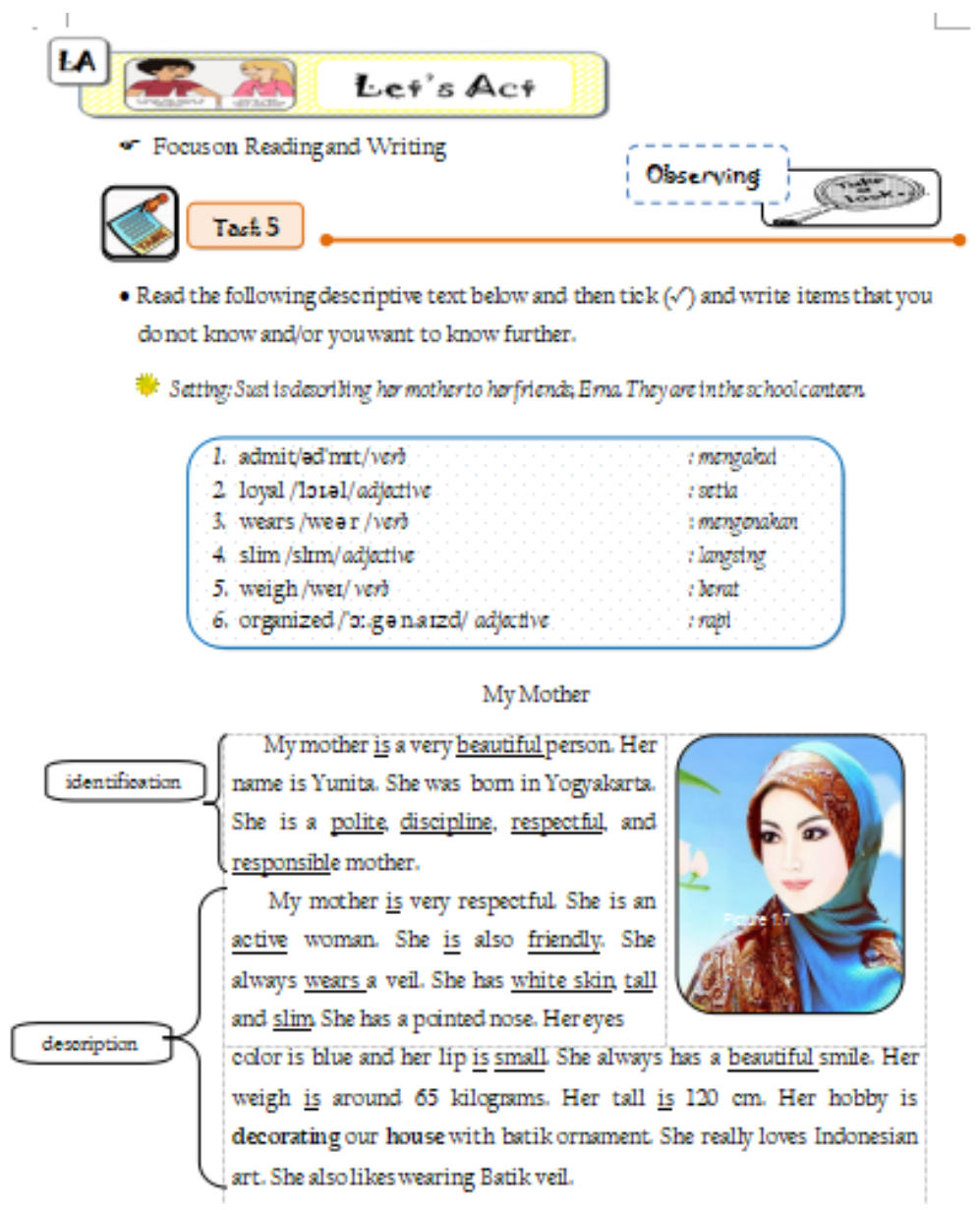

Figure 1. The Example of Reading Activities 


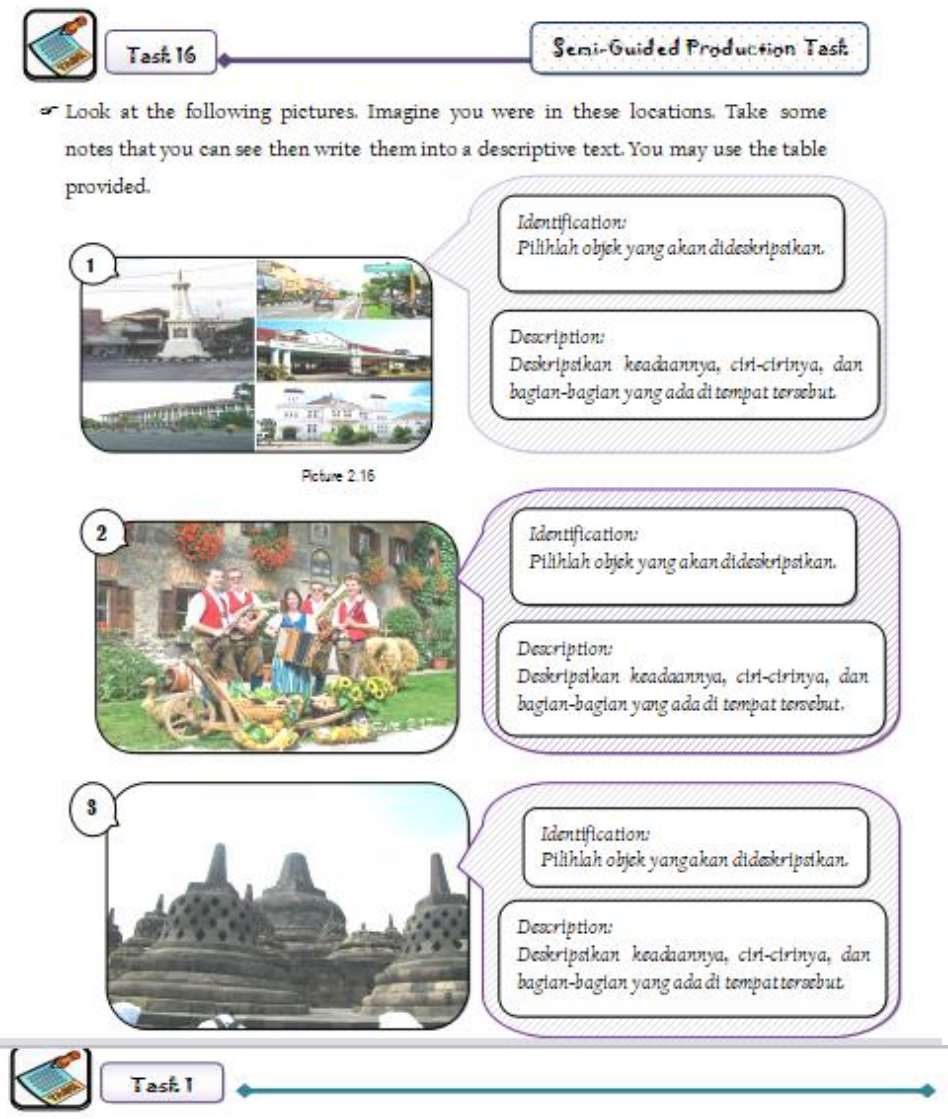

- Look at the following pictures and then complete their personal information. You are allowed to search the information from the internet or ask your history teacher.

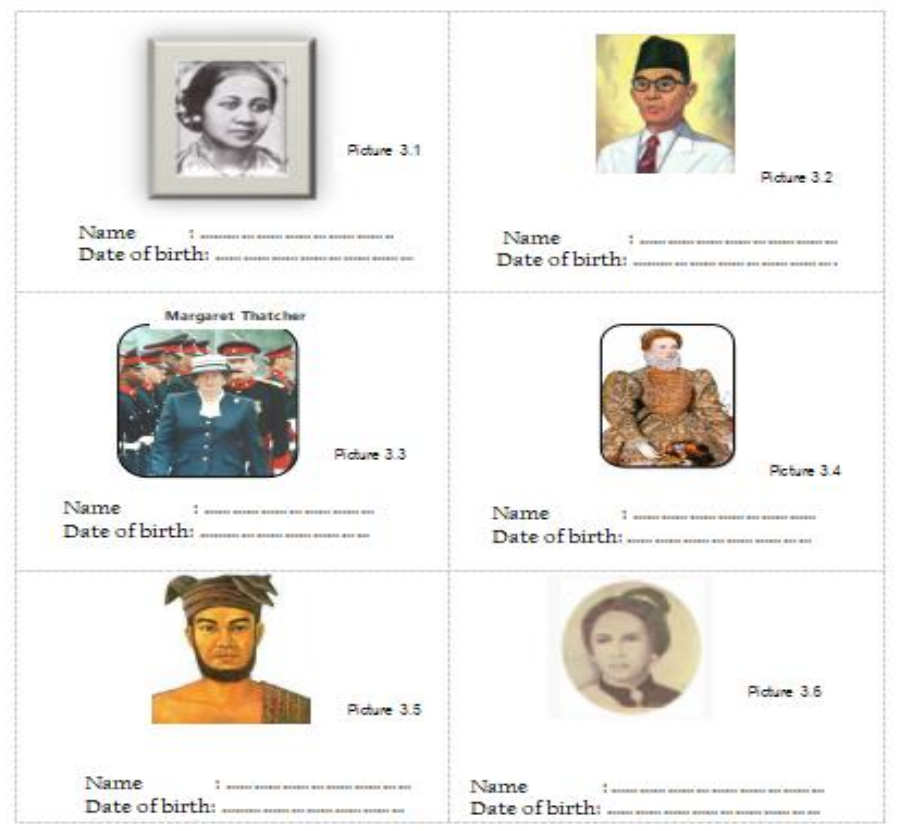

Figure 2. Other Activities 
The last unit was about Foods. The foods were exposed in unit 4 as the last part because the learning materials and learning objectives sequences were in line to the 2013 curriculum syllabus. Additionally, they were emphasizing on how to learn the procedure text. However, the last unit was assumed to be the most interesting topic because the linguistic features served in the unit were more difficult than the previous. Having learnt some either traditional or international foods, students were expected to learn how to make thing carefully and orderly. Furthermore, the cultural values implied in the last unit were helping students to have a good appreciation, nationality, and creativity. One of the activities provided in unit 4 is presented in Figure 3.

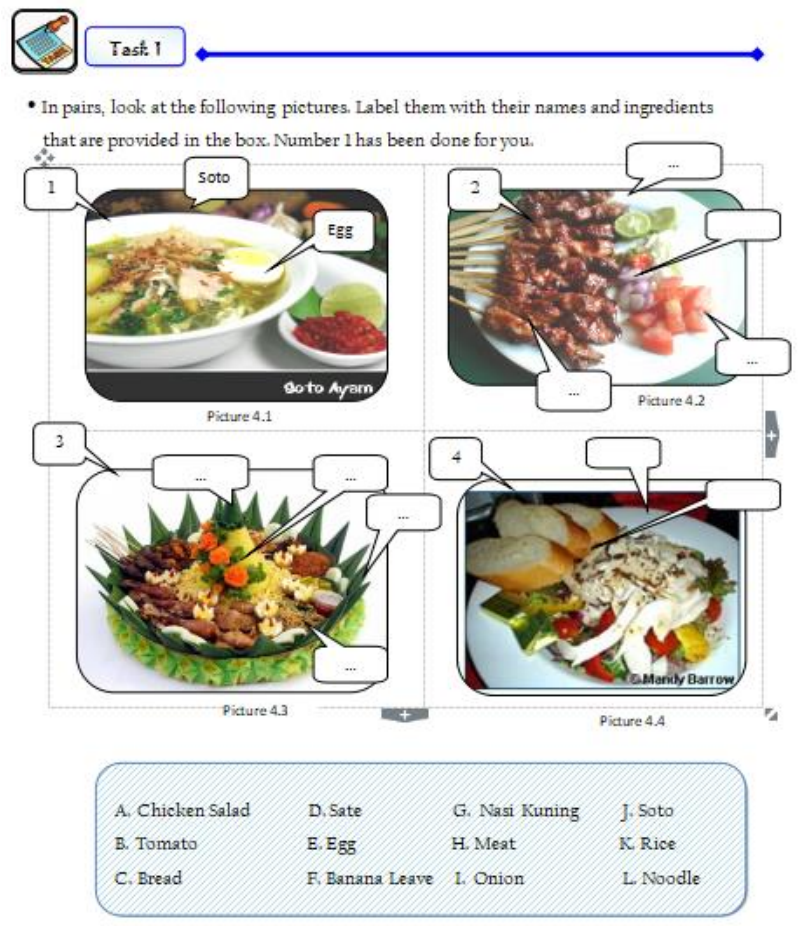

Figure 3. One of the Activities Provided in Unit 4

Every unit comprised some general parts. They were: 1) let's get ready which gave the student opportunities to acquire some new words. In that part, there were some activities bundled in sort of tasks such as matching picture, doing crossword puzzle, and so forth, 2) Let's Act was the primary activities. It consisted of task varieties. The task might expose the students to work both individually and in a team. The development of activities in the parts was interrelated. The first activity in the let's act part was started by observing, and then followed by questioning, collecting, analyzing, communicating data. In the end of the activity of the phase, there were let's learning which more emphasized on how to master the grammar which was driven along with let's create. In the let's create, there were three types of activities: 1) guided production task, 2) semi-guided production task, and 3) free production task. 
Starting from the topic of family, historical building and things, the great people, and the food, then the further tasks development would be about things relate to them. A culture corner was set in the middle of the activities with the hope that the students would already get the language inputs. The main purpose of displaying them was aimed at educating the students with the culture's values. An Across Culture was for intercultural competence where the students could get the chance to learn other culture as well as compare the local and target cultures. Let's play the game was a part that aimed at refreshing the class condition. The game had developed relating to the topic thus the students were able to link what they had learnt to the fun activity. Let's do review was the part of evaluation, and then the unit was ended by the last part that was reflection which functioned as the media to communicate between teachers and students responding to all the activities had done in the process of implementing the product. An addition, the reflection part of the culture-based English textbook was also aimed at facilitating students in order to have the opportunities sharing their experiences during the learning process.

\section{Product Evaluation}

To know whether the product of CBEIM was appropriate, it was assessed by the content expert and graphical designer. The content aspect consisted of content, language, learning, culture, and presentation aspects. The content aspect was designed to evaluate materials development, curriculum integration, uniformity of material development with knowledge, skills, and values to support the process of making communication by using English, representations of functional language skills, the strengthen of material development in facilitating students to understand social functions, grammatical features, and generic structure of the text types. Language aspect assessing simplicity of the language, language level, diction, grammatical features, and language appropriateness. Learning aspect assessing appropriateness between developed material and the result of the needs analysis, unit variety development, appropriateness between learning activities and topics, exactness to motivate the students to learn English collaboratively and independently, meaningful of learning activities development, strength of developed material in helping the students to learn the positive values, teachers' role in that process, and the suitability of presented games with the topic. Culture aspect expecting to assess: the cultures integration, relevance of the pictures to the main topic and cultures, pictures and the students' age, attractiveness, and reflection of Indonesian characters, culture corner existence, cross culture, proverb, students' understanding to cultural diversity. Presentation aspects expected to assess: whether the developed material was harmoniously presented among let's get ready, let's act, let's play the game, let's do reviews, and reflection as well as the learning objectives in every unit, and the language inputs presented both in the form of spoken and written texts, learning activities. Graphical design aspects expected to assess materials appearances, attractiveness, the suitability, fonts, typing spaces, punctuation, colors, color 
compositions, the color and text coordination, and pictures and color compositions.

Based on the quantitative data accumulated from the content expert, the product gained the total score of 247 with the average of 4.49. Based on the formulated category, the product was determined to be very good. The following chart and table were indicated the summary of quantitative data derived from the product evaluation.

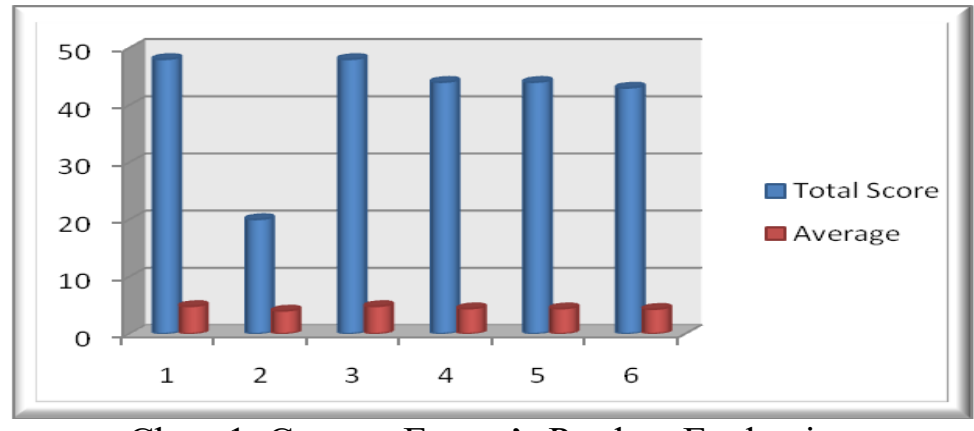

Chart 1. Content Expert's Product Evaluation

Table 4. Content Expert's Product Evaluation

\begin{tabular}{ccccc}
\hline & Aspects & Score & Average & Categories \\
\hline 1 & Content & 48 & 4.80 & Strongly Agree \\
2 & Language & 20 & 4.00 & Agree \\
3 & Learning & 48 & 4.80 & Strongly Agree \\
4 & Culture & 44 & 4.40 & Strongly Agree \\
5 & Presentation & 44 & 4.40 & Strongly Agree \\
6 & Graphic & 43 & 4.30 & Strongly Agree \\
& Total Score & 247 & 4.45 & Strongly Agree \\
\hline
\end{tabular}

\section{Students' English Test Score}

Students' English test score were the students' achievement which meant the entire things achieved by the students. In this context, the students' achievements were all their improvements during the learning process particularly for their cognitive domain. It comprised the students' achievement when they were mastering the English skills.

There were some activities to obtain the students' achievement. The first was by functioning the part of let's do review. The students did the test in the textbook section and then discussed the result with their friends. The second plan was designing the tests. In order to know the students' achievement, the researcher compared the students' previous and current English achievement through the pretest and posttest.

For the particular purpose of the research, results of the students' achievement were used to know how much students could successful learned the skill from the culture-based English textbook. The achievement tests were conducted before and after the treatment. The result then was used as a decision 
on the effectiveness of the product implementation. The following table shows the students' English test both from experiment and control classes covering their pretest and posttest.

Table 5. Students' English Test Score

\begin{tabular}{llccc}
\hline \multicolumn{1}{c}{ Class } & N & Min & Max & Mean \\
\hline Exp. 1 & 68 & 64 & 96 & 80.95 \\
Exp. 2 & 68 & 72 & 100 & 88.77 \\
Contr. 1 & 67 & 56 & 100 & 78.29 \\
Contr. 2 & 67 & 60 & 100 & 82.77 \\
\hline
\end{tabular}

\section{Students' Internalization and Actualization of Culture Values}

After learning the entirely materials provided in four units, students were expected to have a higher internalization and actualization on culture values. There were 25 items with four scales to be used to measure students' level of internalization and actualization of culture values. The questionnaire consisted of seven factors. They were: 1) deserving the value of achievement, 2) self-confidence, 3) creativity, 4) respectful, 5) discipline, 6) nationalism, and 7) tolerance.

The measurement instruments used Likert scale with the option of favorable as the positive response and unfavorable as the negative response. The description of the response comprised: 4. indicated constantly, 3. indicated frequently, 2. indicated infrequently, and 1. indicated never. The description of each category encompassed the maximum score which was around 100 until 25 as the minimum score. The students would be judged to have a very good understanding and manner of acting when their score reached 78 until 100, while they got 63 until 77 signed that they had a good understanding and manner of acting, add to this when the score was less than 62 indicated that the students needed an intensive guidance.

Table 6. Cultural Values Internalization and Actualization

\begin{tabular}{cccc}
\hline Criteria & Descriptions & Student & Percent \\
\hline $\mathrm{A}$ & Very Good & 32 & $47.1 \%$ \\
$\mathrm{~B}$ & Good & 36 & $52.9 \%$ \\
$\mathrm{C}$ & Fair & - & - \\
\hline & Total & 68 & $100 \%$ \\
\hline & & & \\
\hline & & & \\
\hline & & & \\
\hline \\
\hline
\end{tabular}

Chart 2. Internalization and Actualization of Culture Values 
Table 7. Students' Cultural Values Internalization \& Actualization between Experiment and Control Classes

\begin{tabular}{lcccc}
\hline \multicolumn{1}{c}{ Class } & N & Min & Max & Mean \\
\hline Scr.1-Exp. & 68 & 65 & 96 & 77 \\
Scr. 2-Exp. & 68 & 70 & 99 & 80 \\
Scr. 1-Cntrl & 67 & 64 & 90 & 77 \\
Scr. 2-Cntrl & 67 & 69 & 95 & 78 \\
\hline
\end{tabular}

\section{Result of Culture-Based English Textbook Implementation}

To know the representation of culture-based English textbook effectiveness indicated by the students' English improvement and culture values internalization and actualization, statistical analysis for independent sample t-test was applied. T-test for independent sample was used to investigate whether there were any significant differences between the two conditions in the two classes. The statistical calculation was used the gain score. Table 7 showed the student number and their means while Table 8 showed the result of the statistical calculation of independent t-test by the English gain score. The final calculation showed there were any differences between the two groups.

Table 8. Group Statistics of Gain Score of English Test

\begin{tabular}{lcccc}
\hline Classes & N & Mean & Std. Dv. & $\begin{array}{c}\text { Std. Error } \\
\text { Mean }\end{array}$ \\
\hline Exp Class & 68 & 7.823 & 5.77680 & .70054 \\
Ctrl Class & 67 & 4.209 & 8.34037 & 1.01894 \\
\hline
\end{tabular}

Table 9. Independent T-Test with Gain Score

\begin{tabular}{|c|c|c|c|c|c|c|c|}
\hline \multirow[t]{2}{*}{$\begin{array}{c}\text { Gain } \\
\text { Score of } \\
\text { English } \\
\text { Test }\end{array}$} & \multicolumn{2}{|c|}{$\begin{array}{l}\text { Levene's Test } \\
\text { for Equality of } \\
\text { Variances }\end{array}$} & \multicolumn{5}{|c|}{$\begin{array}{c}\text { t-test } \\
\text { for Equality of Means }\end{array}$} \\
\hline & $\mathrm{F}$ & $\begin{array}{c}\text { Sig } \\
\text {. }\end{array}$ & $\mathrm{t}$ & $\mathrm{df}$ & $\begin{array}{c}\text { Sig. } \\
(2- \\
\text { tailed })\end{array}$ & $\begin{array}{c}\text { Mean } \\
\text { Differe } \\
\text { nce }\end{array}$ & $\begin{array}{c}\text { Std. } \\
\text { Error } \\
\text { Differen } \\
\text { ce }\end{array}$ \\
\hline $\begin{array}{c}\text { Equal } \\
\text { variances } \\
\text { assumed }\end{array}$ & 2.946 & $\begin{array}{c}.08 \\
8\end{array}$ & $\begin{array}{c}2.93 \\
1\end{array}$ & $\begin{array}{c}13 \\
3\end{array}$ & .004 & $\begin{array}{c}3.6145 \\
7\end{array}$ & 1.23328 \\
\hline
\end{tabular}


Table 10. Students' Gain Score of Culture Values Internalization and Actualization

\begin{tabular}{cccccccc}
\hline $\begin{array}{c}\text { Gain Score of } \\
\begin{array}{c}\text { Culture } \\
\text { Values }\end{array}\end{array}$ & $\begin{array}{c}\text { Levene's Test } \\
\text { for Equality of } \\
\text { Variances }\end{array}$ & & & & \multicolumn{3}{c}{$\begin{array}{c}\text { t-test } \\
\text { for Equality of Means }\end{array}$} \\
\cline { 2 - 8 } & F & Sig. & t & df & $\begin{array}{c}\text { Sig. } \\
(2-t a i l e d)\end{array}$ & $\begin{array}{c}\text { Mean } \\
\text { Difference }\end{array}$ & $\begin{array}{c}\text { Std. Error } \\
\text { Difference }\end{array}$ \\
$\begin{array}{c}\text { Equal } \\
\text { variances } \\
\text { assumed }\end{array}$ & 2.523 & .115 & 2.524 & 133 & .013 & 2.28709 & .90608 \\
\hline
\end{tabular}

Based on the data gathered, the result showed that there were significant differences between the two groups. The experiment class got a higher score on the culture values internalization and actualization indicated by significant differences among them because they can internalize and actualization the cultural values. The culture values provided in the textbook helped the students to learn. The outlying critical district that the significant value was smaller than the alpha or the $\mathrm{p} \leq \alpha$ (significance of $5 \%$ or 0,05 ) was obvious from the Table 9.

\section{FINDINGS AND DISCUSSION}

Based on the overall descriptions referring to the tryout result, the product was determined to be effective. The assumptions were based on several arguments. The first, the students could show their increase significantly in understanding English materials after learning it using the culture-based English textbook. The finding was in fact in line to research finding done by Doganay, Ashirimbetova, \& Davis (2013). They found that with culture integration, students could improve their English communicative and linguistic competences. The second, it showed there were differences between the students who were taught by the culture-based English textbook and those who were not. The third, since the culture-based English textbook was filled with cultural values; teachers could motivate and support the students to consider those values in their life. The fourth, since the evaluation from the content expert on the textbook got a higher appreciation, thus it indicated that the culture-based English textbook was feasible and recommended to be used in the English teaching and learning process for Junior High School Students in grade VII.

In addition, observation also was done to observe the class condition and the students' preferences. Those were aimed at being alert of the social bias from the students. Realizing the complexity of the research in gaining the data, the observations were designed as an experimental observation in which they 
were done to record the prepared condition in those classes. The point in conducting the observation was how the culture-based English textbook was being implemented in the class and how far the students could increase their cognitive and affective development: English competence, internalizing, and actualizing the culture values.

There were three important landmarks recorded during the observation: 1) how the Culture-based English Textbook could help teachers in teaching English and culture values. 2) How the Culture-based English Textbook could help students in learning English and understanding the culture values, and 3) whether students were seriously internalized and actualize the culture values in their daily life. The three landmarks were briefly described in the following's parts.

The Culture-based English textbook helped the teacher in teaching English and culture values because the instructional materials were developed based on the culture-based concept. This idea was supported by Kramsch's theory (1998) convincing that language showed kind of expressions. The expressions could be used to symbolize cultural reality. Therefore, language and culture were bounding together. As a result, integrating culture values in instructional materials were a good choice to do. The teacher utilized some reading texts that consisted of culture values in which they were used to stimulate students to be well behaved. The example of culture values exploration was taken from the unit 3 in which it discussed about the great people.

Based on the observation, the teacher started teaching by leading the students to pray together and checking the students' attendance. Having made sure the student's condition, the teacher started announcing the learning goals of that day and then continued presenting some great people through the classroom screen projector. While seeing and observing the pictures on the screen, students also used their culture-based English textbook that had already been distributed by the researcher.

The teacher started giving a simple description of the pictures. However, she stimulated students to mention some of good personalities from the picture (such as R.A. Kartini and Cut Nyak Dien) and then students mentioned their good personalities. The teacher also guided students in pronouncing the words used to describe the picture personalities. The following pictures showed the small portion of the class activities.

Students were challenged to mention some personalities based on the pictures. Some attempted to mention spontaneously and some attempted to write the words on the white board. When they did not have the words to say, they opened their dictionary and found them. However, some of the personality's terms were presented in the textbook and it could be found in page 68 of the textbook. Students were also allowed to do the vocabulary enrichment from the page. Before they read the reading passage about the great people, they had acquired some related words. Acquiring new words before reading the passage was helpful and it made them easy to understand the text.

Based on that observation, it showed that both students and teachers were helped by the culture-based English textbook. Since then it was equipped with 
some pictures, vocabularies, pronunciation guide, thus students could easily use it independently. The teachers also drilled the students in pronouncing the words that related to the great people' personalities as well as reminded them to memorize the words meaning. Students together read aloud the words by considering the pronunciation then students were given time to list several good personalities from the great people they learn.

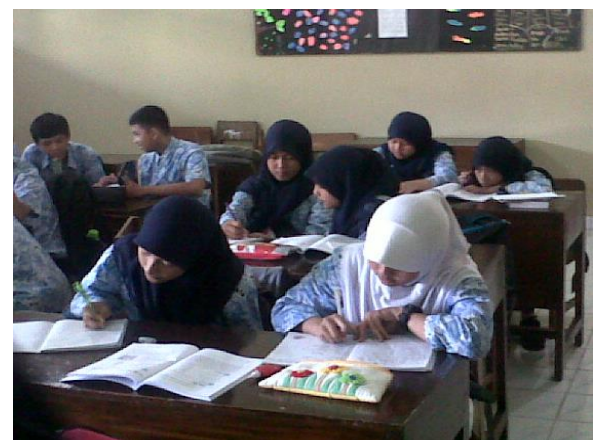

Figure 4. Listing Good Personalities from Great People

The culture-based English Textbook could help students in learning English and understanding good values. Take for example when they read the reading passage about people who had good personalities, at least they were inspired and motivated to be and to do the same things. While reading, they also found some underlined words in which they were used to attract the students' attention to learn about grammar implied in the passage and the technical words, synonym, and antonym related to the reading topic. The Figure 6 was used to encourage students to have a respect to the older people. 
- In pairs, study the following a descriptive text and pay attention to the organization of the text. Don't forget to remember the language features.

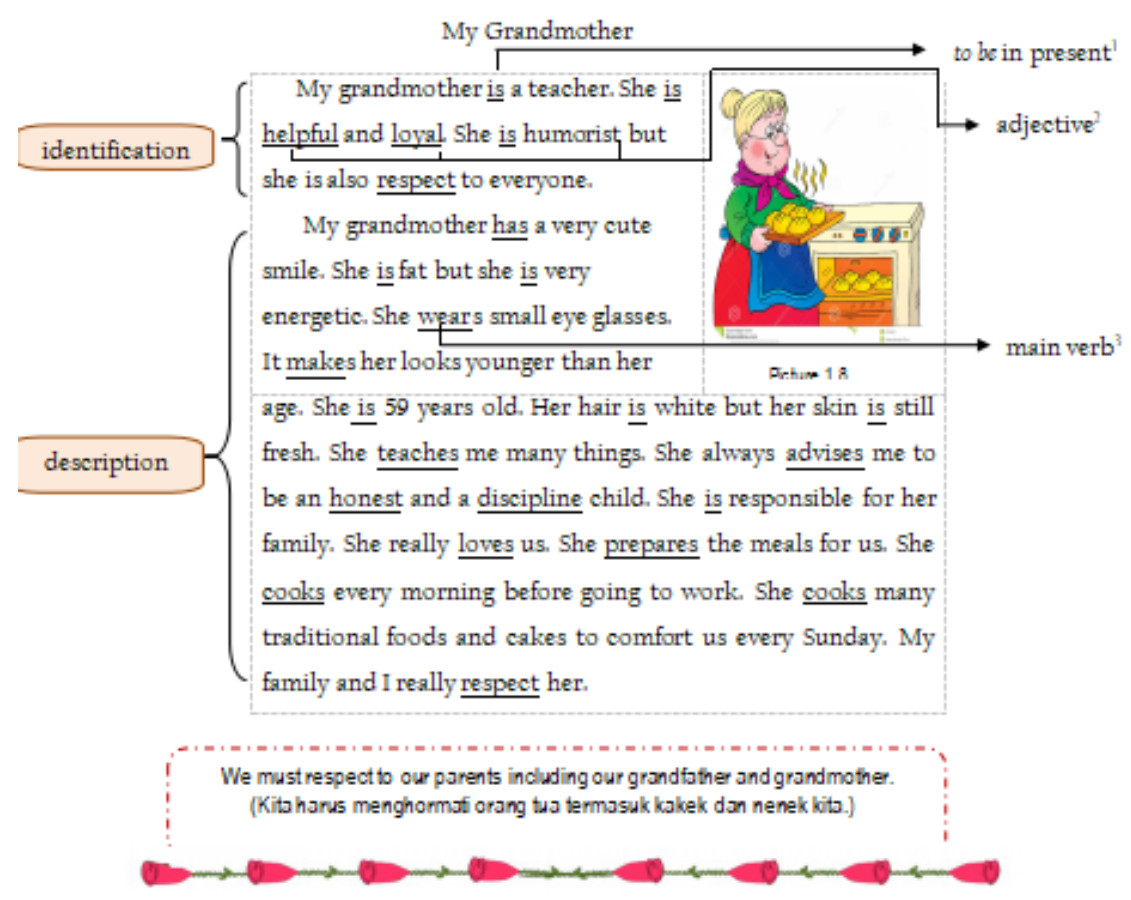

Figure 5. Reading Text in Unit 1

Based on the observation, during the culture-based textbook implementation, the students seriously internalized the culture values from the reading passage. Those landmarks were captured during the teaching and learning process. Those were also proven by the students' reaction in reading the text and the way their responses to the teacher's command. Apparently, there were some students who wrote a part of the textbook content such as the fun time what were served in across culture in page 76. Most of them also requested the teacher to play the game in the end of the class session. However, there were few of them who had the same preferences such as having lack of attention to the teacher' explanation. Despite listening to her explanation, they did the vocabulary enrichment and seeing the pictures of the textbook on and on while talking and chatting with their classmate.

From the whole observation, it showed that students were able to learn English maximally. They were also motivated to practice English by doing a simple conversation with their classmate. This finding supported Kramsch's theory (1993) that culture could be created and learnt through dialogue among students and between students and teachers. Their English competence also got its significant progress. When the teacher gave them time to work in group, 
they also did respectfully. They did the work together in their team and able to submit the project based on the time allocation and its deadline. By working together in a team, students were helped to understand the lesson easily. They were also able to build their confidence when they worked in a group. In the end of the session, students used their rest of their time by playing games enclosed in the end of the unit. The Figure 7 is the example of the game appearance.

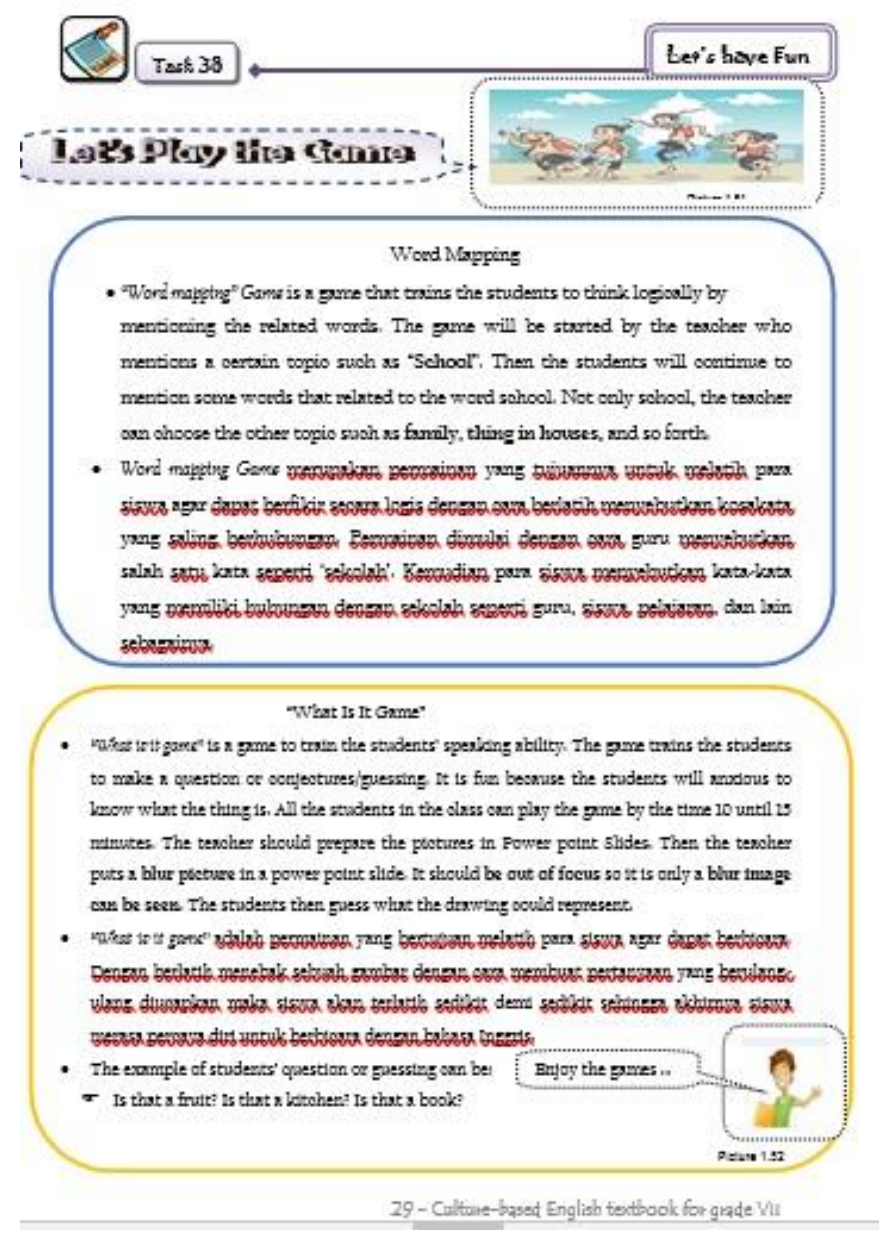

Figure 6. The Games Appearance

\section{Discussion of the Final Product}

The product had been developed based on the determined standards of the research. CBEIM had proven to have a better quality as the supplementary textbook for Y-SJHS. The product was able to enhance and to increase the students' English skill. Furthermore, the level of students' internalization and actualization toward cultural values understanding were also increased. The finding then supported the research finding done by Syatrian, et al. (2013) that students got easily of comprehending the English lesson when the instructional materials were served based on the local contents. That was the empirical 
evidence showing the product had its own novelty. Since there were two landmarks in this research: 1) how to develop the product, and 2) how was the effectiveness of the product. Therefore, there were some parts followed them.

The process of product development consisted of conducting the need analysis which the result of it was used to design the product. While designing the product, there were some topics and learning activities considered to be a part of the instructional materials. Kind of topics which were developed in the product were 1) family, 2) historical building and things, 3) great people, and 4) the foods, while the learning activities covered work individually and collaboratively. The developed of learning activities were based on the skills, such as reading the text, answering the questions, listening and imitating, making a dialogue or writing a text based on the provided picture. One of the most important things to do in that product development, the researcher attempted to integrate the cultural values into the text.

There were two ways in integrating the cultural values in that product; explicitly and implicitly. The way to integrate the culture values explicitly was by developing some text that directly exposed the good moral which appeared from the characters of the texts and by giving some additional quotation in the form of proverb or culture corner where the students could read and learn the moral messages from them. Then the way to integrated implicitly was by presenting some pictures and some learning activities in the culture-based English textbook. After the product had been finished developed by the researcher, then it was time to bring them to the content expert judgment. That was the time for the researcher to get any suggestion improving the product. By doing that ways, it was expected that the moral and/or positive cultural values integration in the product could support the students to internalize and actualize them in their daily life.

The effectiveness of the product included: 1) the finding whether there was any significant increase toward the students' English test score before and after the culture-based English textbook implementation, 2) emerging a significant difference between the students' English test score in experiment and controlled classes, 3) as well as were there any increase to the students' level of internalization and actualization toward cultural values. From the process of product implementation, it revealed that the product of culture-based English textbook could support the teaching and learning process to be more effective. It showed that the students' English score significantly increased, and they also demonstrated their progress on internalizing and actualizing the cultural values.

\section{CONCLUSION}

The way to develop the product was started by conducting the need analysis then the result was used to consider in designing and developing CBEIM. The materials developed in the research product covered the Indonesian culture and English culture such the family, historical buildings and things, great people, and foods. Those culture values were presented in reading and listening, monologue and dialogues both in written and spoken text. They were integrated explicitly and implicitly such as through texts, images, and 
students' activities. After the product had been developed then it was validated by the content expert and graphical design expert.

The product had proven to be effective since there was significantly increase of the students' English test score after learning English using the product. The students' posttest from the experiment class revealed a higher than in the control class. Based on the statistical calculation of independent samples test with gain score from the two groups, the $t$ values were 2,931 with the $p$ values was 0,004 . Hence it indicated that there was a significance difference between of the two classes since $p=0,004<0,05$ (with level of significance $95 \%$ ). It was caused by the mean of the gain score was 7.8235 from the experiment class and 4.2090 from the control class. The product also got its superior for it was able to support the students in internalizing and actualizing the culture values provided in the all units such as encouraging them to deserve achievement, confidence, creative, respect, discipline, tolerance and have a high nationalism. Having calculated the gain score of culture values from the two groups, the experiment class mean was 2.7647 while the control class was 0.4776 .

\section{REFERENCES}

Atkinson, D. (2012). Intercultural rethoric and intercultural communication. In J. Jackson (Ed.), The routledge handbook of language and intercultural communication. London and New York: Routledge.

Dick, W., Carey, L., \& Carey, J. O. (2005). The systemic design of instruction $\left(6^{\text {th }}\right.$ Ed.). Boston: Pearson.

Doganay, Y., Ashirimbetova, M., \& Davis, B. (2013). Making culture happen in the english language classroom. Journal of English Language Teaching; Vol. 6, (10), 11-15.

Dudley-Evans, T., \& St John, M. J. (1998). Developments in English for specific purposes: A multi-disciplinary approach. Cambridge: Cambridge University Press.

Graves, K. (2001). A framework of course development process. In D. R. Hall, \& A. Hewings (Eds.), Innovation in English language teaching: A Readers. New York: Routledge.

Hariyantina, A., Arifuddin, \& Djuhaeni, E. (2015). The relevance of the english textbook to the syllabus of curriculum 2013 at grade VIII SMP N 1 Gunungsari (2015/2016). Mataram: University of Mataram.

Ho, S. T. (2009). Addresing cultural in EFL classrooms: The Challenge of Shifting from a Traditional to an Intercultural Stance. Journal of Foreign Language Teaching, 6 (1), 63-76. 
Kanoksilapatham, B. (2014). Developing young learners local culture awareness and global English: Integrated Instruction. International Journal of Information and Education Technology, 5 (9), 676-682.

Kramsch, C. (1993). Context and culture in language teaching. Oxford: Oxford University Press.

Lorenzutti, N. (2014). Beyond the gap fill: Dynamic Activities for Song in the English Foreign Language Classroom. English Teaching forum, 52 (1), 14-21.

Mursyida, N. (2015). Teachers' perspective on the textbook "When English Rings the Bell”. Banda Aceh: English Department Faculty of Education and Pedagogy. Faculty of Education and Pedagogy State Islamic University Ar-Raniry Darussalam - Banda Aceh.

Nation, I., \& Macalister, J. (2010). Language curriculum design. New York \& London: Routledge.

Rulani, Y., Asep, K., Gunawan, \& Wachi, S. (2014). Bahasa Inggris, When English Rings a Bell Kelas 7 SMP. Jakarta: Pustaka Kurikulum dan Perbukuan Kementerian Pendidikan dan Kebudayaan.

Saifer, S., Edwards, K., Ellis, D., Ko, L., \& Stuczynski, A. (2011). Culturally responsive standards-based teaching: Classroom to Community and Back. California: Corwin.

Syatriana, E., Husain, D., Haryanto, \& Jabu, B. (2013). A model of creating instructional materials based on the school. Journal of Education and Practice, 4 (20), 10-18.

Tan-Florendo, Z. (2012). Instructional material for writing in the discipline. International Scientific Research Journal, 4 (3) 158-170.

Tomlinson, B. (2008). English language learning materials. London: Continuum International Publishing Group.

Tomlinson, B. (2012). Materials development for language learning and teaching [electronic version]. Cambridge Journal, p.143-179.

Zuchdi, D. (2009). Humanisasi pendidikan: Menemukan Kembali Pendidikan Yang Manusiawi. Jakarta: Bumi Aksara. 